\title{
Effects of Soil Conditions on Root Rot of Soybean Caused by Fusarium graminearum
}

\author{
D. R. Cruz, ${ }^{1,2}$ L. F. S. Leandro, ${ }^{1}$ D. A. Mayfield, ${ }^{1,2}$ Y. Meng, ${ }^{3}$ and G. P. Munkvold ${ }^{1,2, \dagger}$ \\ ${ }^{1}$ Department of Plant Pathology and Microbiology, Iowa State University, Ames, IA 50011, U.S.A. \\ ${ }^{2}$ Seed Science Center, Iowa State University, Ames, IA 50011, U.S.A. \\ ${ }^{3}$ Department of Plant Pathology, China Agricultural University, Beijing 100193, P.R. China \\ Accepted for publication 6 May 2020.
}

\begin{abstract}
Fusarium graminearum is an important soybean pathogen that causes seedling disease, root rot, and pre- and postemergence damping-off. However, effects of soil conditions on the disease are not well understood. The objective of this greenhouse study was to determine the impacts of soil texture, $\mathrm{pH}$, and soil moisture on seedling root rot symptoms and detrimental effects on seedling development caused by $F$. graminearum. F. graminearum-infested millet was added (10\%, vol/vol) to soil with four different textures (sand, loamy sand, sandy loam, and loam). Soil moisture was maintained at saturation, field capacity or permanent wilting point at soil $\mathrm{pH}$ levels of 6 or 8. Seedlings were evaluated 4 weeks after planting for root rot, root length, root and shoot

texture for root rot assessed visually $(P<0.0001)$. Highest severity (67\%) and amount of F. graminearum DNA were observed at $\mathrm{pH} 6$ and permanent wilting point in sandy loam soils. Pot saturation resulted in the lowest levels of disease in sandy loam and loam soils (11.6 and $10.8 \%$, respectively). Reductions in seedling growth parameters, including root length, foliar area, shoot and root dry weights, and root tips, relative to the noninfested control, were significantly greater in sandy loam soils. In contrast, there were no significant growth reductions in sand. This study showed that levels of root rot increased under moisture-limiting conditions, producing detrimental effects on plant development.
\end{abstract} dry weights, leaf area, and $F$. graminearum colonization (by qPCR). There was a significant interaction between soil moisture and soil

Fusarium graminearum (synonym Gibberella zeae (Schwein.) Petch) is a major necrotrophic pathogen of soybean, causing pod blight, seed decay, damping-off, and crown and root rots in the United States, Canada, and other temperate regions (Martinelli et al. 2004; Sella et al. 2014; Xue et al. 2007). Soybean is often included in rotation with wheat, maize, and other cereal crops that are $F$. graminearum hosts; $F$. graminearum colonizes and overwinters on these crop residues providing a source of inoculum for subsequent seasons (Barros et al. 2014; Leslie et al. 1990; Windels et al. 1988). F. graminearum isolates that colonize wheat and maize have been found to be highly pathogenic on soybean (Broders et al. 2007). Xue et al. (2007) suggested that soybean and cereal crop rotations provide strong selection pressure for the development of highly aggressive $F$. graminearum isolates on all crops. Isolates of $F$. graminearum from soybean in the Central United States have been characterized as 15-ADON genotypes of $F$. graminearum sensu stricto (Ellis and Munkvold 2014). Other trichothecene genotypes have not been reported from soybean, to our knowledge.

There are reports of $F$. graminearum being highly prevalent and associated with soybean seedlings causing severe root rot in Iowa (Díaz Arias et al. 2013a, b). Seedling diseases caused by diverse fungi and Oomycetes generally are prevalent when soil temperatures are low and soil moisture is high. These conditions delay germination and emergence, increasing the probability of seed and seedling infection (Broders et al. 2007; Licht et al. 2013).

†Corresponding author: G. P. Munkvold; munkvold@iastate.edu

Funding: This research was funded by the United Soybean Board and the North Central Soybean Research Program.

The author(s) declare no conflict of interest.

(c) 2020 The American Phytopathological Society
Keyword: mycology

Disease severity for root pathogens is influenced by soil physiochemical conditions and biodiversity in soil microbial populations (Ghorbani et al. 2008). However, there is a lack of detailed knowledge about soil environment and soil conditions such as $\mathrm{pH}$, soil texture, and soil moisture that influence disease development, incidence and severity of Fusarium root rot of soybean caused by $F$. graminearum.

Soil $\mathrm{pH}$ influences root rot severity by directly affecting soil microbial communities and the balance between pathogens and their specific antagonists (Hoper and Alabouvette 1996). Evidence suggests that lowering soil $\mathrm{pH}$ from 8 to 6 on Fusarium-suppressive soils drastically reduces the viability of Pseudomonas spp. and eliminates the suppressive effects on Fusarium wilt diseases (Scher and Baker 1980). Similarly, changes in soil $\mathrm{pH}$ indirectly affect nutrient availability to the pathogen and the plant host (Ghorbani et al. 2008).

Soybeans are sensitive to changes in soil $\mathrm{pH}$; highest soybean yields in Iowa and Minnesota have been reported at soil $\mathrm{pH}$ levels between 6.2 and 7.0 (McLean and Brown 1984; Rogovska et al. 2007). Altered nutrition induced by soil acidity can increase or decrease the susceptibility of the plant host, affecting disease severity and incidence (Fang et al. 2012; Ghorbani et al. 2008). Under high soil $\mathrm{pH}$, iron availability is reduced and pathogen establishment will depend on the ability to acquire and compete for iron. F. graminearum has two types of iron acquisition systems, secretion and uptake of iron-chelating molecules and production of cell wall iron reductases to reduce ferric iron to ferrous iron (Greenshields et al. 2007; Kosman 2003; Philpott 2006). Iron availability also affects soybean plants and can lead to iron deficiency chlorosis (IDC) in high pH soils (Rogovska et al. 2007). Soybean plants with IDC symptoms often display root rot symptoms, but the basis of this association is not clear.

Soil texture can also affect pathogen distribution in soil and plant resistance to disease. Fusarium wilts have been commonly associated with sandy soils (Dominguez et al. 1996; Toussoun 1975). For example, field observations have shown that Fusarium 
wilts caused by $F$. oxysporum are more severe in coarse sandy soils or loamy-textured soils, and clayey soils seem to be suppressive (Hoper and Alabouvette 1996; Scher and Baker 1980; Yuen et al. 1983). However, associations between Fusarium root rot of soybean caused by $F$. graminearum and soil texture components have not been documented. Soil texture and type of clay have been correlated to disease incidence and severity in a diverse number of Fusarium wilts on muskmelon, banana, flax, barley, and tobacco (Alabouvette et al. 1979; Dominguez et al. 1996; Hoper et al. 1995; Strunnikova et al. 2015; Stutz et al. 1989; Toussoun 1975).

Bacteria actively interact with soil clay minerals due to the high cationic exchange capacity (CEC), large surface area and variable negative charge (Hoper and Alabouvette 1996); these interactions consist mainly of buffering soil $\mathrm{pH}$, providing available nutrients that can be rapidly used. Addition of clay minerals into the soil reduces the availability of iron to fungal pathogens, promoting bacterial growth (Hoper et al. 1995). High clay CEC stimulates the metabolism of bacteria (Stotzky and Rem 1966). In contrast, siltsand minerals are considered less active (Robert and Chenu 1992).

Soil texture is related to different physical soil characteristics such as the distribution of pore sizes, soil structure, and soil water potential; these soil attributes determine the habitable space and distribution of bacteria and fungi (Hoper and Alabouvette 1996). Soil texture and soil water holding potential also contribute to host growth, root architecture, and pathogen resistance (Ali and Ghaffar 1991; Krizek et al. 1985; Lynch and Vanbeem 1993).

Depending on the pathosystem, low and high soil water potential may have different effects on root rot. For example, in $F$. oxysporum-infested soils near saturation, soybean root rot severity increased, but only at low soil temperatures (French 1963). Field observations indicate that three or 7-day duration of flooding at soybean emergence increase incidence and severity of Pythium spp., whereas at the same time Fusarium spp. tend to be less frequently associated with seedling infection under flooded conditions (Kirkpatrick et al. 2006). On the other hand, low water potentials may predispose the host to infection and favor diseases such as dry rot of beans caused by $F$. solani and seedling blight of cereals caused by $F$. roseum (Ghorbani et al. 2008; Hoper and Alabouvette 1996). Fusarium root rots of sweet potatoes, peas, and beans are also increased by dry soil conditions (Cook and Papendick 1972). In addition, several Fusarium wilt diseases are favored by dry soil conditions; Fusarium wilt of chickpea caused by F. oxysporum f. sp. ciceris (Landa et al. 2006; Navas-Cortes et al. 2007), seedling blight of clover caused by F. roseum (Graham et al. 1957), and root and stem rot of peas and chickpeas caused by F. solani f. sp. pisi (Bhatti and Kraft 1992).

The objectives of this research were to measure the effects of important soil variables on the development of root rot of soybean caused by $F$. graminearum by studying (i) the effects of soil $\mathrm{pH}$ and soil water content interaction on root rot, (ii) the effects of artificial soil textures and its interaction with soil $\mathrm{pH}$ and soil water content on root rot, and (iii) the possible detrimental effects on soybean seedling growth parameters under various edaphic conditions on F. graminearum-infested soils.

\section{MATERIALS AND METHODS}

Inoculum production. $F$. graminearum isolate FG5 was collected from symptomatic soybean roots in Iowa in 2007, single-spored, identified to species microscopically and by DNA sequencing (Díaz Arias et al. 2013b), and maintained on dry silica gel beds at $4{ }^{\circ} \mathrm{C}$ until use. Aggressiveness and pathogenicity of the FG5 isolate was tested on soybean cultivar Asgrow 2403 (SDS susceptible) (Monsanto Co., MO) under greenhouse conditions (Díaz Arias et al. 2013a).

Millet seeds were soaked for $24 \mathrm{~h}$ in water, drained and autoclaved at $121^{\circ} \mathrm{C}$ for $1 \mathrm{~h}$ in autoclave bags with a microporous filter patch on two consecutive days. Isolate FG5 was grown on potato dextrose agar (PDA) $39 \mathrm{~g} /$ liter (Difco, Becton, Dickinson and $\mathrm{Co}, \mathrm{MD})$ for 14 days in an incubator at $25^{\circ} \mathrm{C}$ with a $12-\mathrm{h}$ photoperiod, to promote conidial formation. Plugs $\left(\sim 1 \mathrm{~cm}^{2}\right)$ from cultures of FG5 were added to the sterile millet in a biosafety cabinet and then sealed with a rubber band. Bags were then placed in an incubator (Hoffman Manufacturing Inc., OR) for 8 days, at $65 \%$ relative humidity with a $12 \mathrm{~h}$ photoperiod, and mixed by hand every day. FG5-infested millet was mixed with soil at $10 \%$ concentration by volume.

Artificial soil textures. Four artificial soil textures (sand, loamy sand, sandy loam, and loam) were created by mixing sand and silt loam in different proportions by volume (Table 1). Resulting textural classes on the artificial soils were analyzed for particle size distribution following the protocol by the National Soil Survey Center (1996). Soils were pasteurized in a soil steamer with a steam generator SG670 and steam aerator SA700 (Lindig Manufacturing, Co., $\mathrm{MN}$ ) for $1.5 \mathrm{~h}$, dried on a plastic sheet on a greenhouse bench for 4 days and kept in closed plastic containers until use.

Soil $\mathbf{p H}$. Initial soil $\mathrm{pH}$ for each soil textural class was measured by the electrometric standard method, using a 1:1 soil/water ratio (Watson and Brown 1997). Ten milliliters of distilled water was added to $10 \mathrm{~g}$ of soil in a 50-ml falcon tube, shaken for $10 \mathrm{~min}$ and settled for $5 \mathrm{~min}$, placing the $\mathrm{pH}$ meter electrode in the slurry. After the initial $\mathrm{pH}$ measurements, soil $\mathrm{pH}$ was adjusted to 6 or 8 by gradually adding $\mathrm{Al}_{2}\left(\mathrm{SO}_{4}\right)_{3}$ (Bonide Products, Inc., NY) and $\mathrm{CaCO}_{3}$ (Fisher, IL) to the soil, respectively. Soils were then wet, dried, and mixed twice a day for 2 weeks to allow the soil to react with the chemical compounds. Soil $\mathrm{pH}$ measurements were performed periodically until the soil remained at constant $\mathrm{pH}$ equilibrium (Islam et al. 2004).

Soil moisture content. Three levels of soil moisture including pot saturation (PS), field capacity (FC), and permanent wilting point (PWP) were set for each soil texture, derived from the volumetric water content $\left(\theta_{\mathrm{v}}\right)$ points for different textural classes described by Rowell (1994) and Brady and Weil (2004) (Table 2). For each soil textural class, $230 \mathrm{ml}$ of dried soil was weighed in a $350-\mathrm{ml}$ Styrofoam cup, and a calculation of the volume of water needed for each type of soil texture was performed by using the following formula: $V_{w}=V_{s} \times \theta_{v}$, where $V_{w}$ is the volume of water contained in a soil, $V_{s}$ is the total volume of soil, and $\theta_{\mathrm{v}}$ is the soil volumetric water content point. The weight of $230 \mathrm{ml}$ of soil for each soil textural class and the weight of the water needed to reach the desired water content point were added to have a final weight per cup that was subsequently maintained by adding water once a day.

Soil infestation and experimental design. After 2 weeks of incubation, inoculum was mixed with soil at $10 \%$ concentration by volume. Noninfested control treatments contained $10 \%$ autoclaved sterile millet. Seeds of soybean cultivar Jack were surface disinfested in $0.5 \% \mathrm{NaOCl}$ for $2 \mathrm{~min}$, rinsed twice for $2 \mathrm{~min}$ in sterilized distilled water, and dried for $20 \mathrm{~min}$ in a laminar flow hood before planting. Three seeds per cup were planted into the infested or noninfested soil mix and watered daily for 2 weeks. Soil moisture levels PS, FC, and PWP were imposed 2 weeks after planting and maintained for 2 weeks. Four weeks after planting, seedlings were visually rated for root rot severity from 0 to $100 \%$ of roots with brown or black discoloration, roots were scanned using a flatbed scanner (EPSON Expression, 10000XL, Epson America, Inc.), and root images were analyzed using WinRhizo software 2008 (Regent Instruments Inc., QC, Canada) to obtain estimates of root length, surface area, root volume, root tips, and forks on each individual plant. In addition, foliar area was estimated on individual plants using Assess 2.0 (The American Phytopathological Society [APS], St. Paul, MN). Shoot and root dry weights were measured on each individual plant after oven drying at $80^{\circ} \mathrm{C}$ for $24 \mathrm{~h}$. Percentage reduction of seedling growth parameters was calculated measuring root length, foliar area, root dry weight, shoot dry weight, root volume, and root tips on each plant from the soil infested treatments and then dividing by the average measure of the noninfested control 
on each soil texture, soil moisture, and soil $\mathrm{pH}$ combination treatment and multiplying by 100 . The experiment was organized in a split-plot design with soil moisture (PS, FC, and PWP) as the main-plot factor, and soil texture (sand, loamy sand, sandy loam, and loam), soil $\mathrm{pH}$ (6 or 8), and $F$. graminearum-infested or noninfested soils as subplot factors. One cup was considered as an experimental unit with three seeds or subsamples in each cup. The experiment had eight replications per treatment combination and was conducted twice.

DNA extractions. DNA was isolated from root samples obtained from plants growing in the greenhouse at soil $\mathrm{pH} 6$ after 30 days. Twenty-four roots (biological replicates) per treatment combination were arbitrarily selected, washed under tap water, surface-disinfested in $0.5 \% \mathrm{NaOCl}$ for $2 \mathrm{~min}$, rinsed three times in sterilized distilled water, air-dried, lyophilized for 2 days, ground in liquid nitrogen with a sterile pestle, and stored at room temperature until use. Root DNA was extracted using a modification of the CTAB (2\%) procedure by Doyle and Doyle (1987), and purified in the KingFisher Flex Magnetic Particle Processor System using the MagMAX Plant DNA isolation kit A32549 (Applied Biosystems, CA).

For fungal DNA extraction, the FG5 isolate was grown on potato dextrose broth in $125-\mathrm{ml}$ plastic flask for 5 days in an incubator at $25^{\circ} \mathrm{C}$ while shaken at $125 \mathrm{rpm}$. The fungal tissue and broth were strained through cheesecloth, lyophilized for 1 day, ground in liquid nitrogen, placed in a $1.5-\mathrm{ml}$ tube, and frozen at $-80^{\circ} \mathrm{C}$ until use. Genomic DNA of mycelia were extracted by the CTAB $(2 \%)$ method.

The concentration of the DNA (ng per $\mu \mathrm{l})$ and ratios of absorbance $\left(\mathrm{A}_{260} / \mathrm{A}_{280}\right.$ and $\left.\mathrm{A}_{260} / \mathrm{A}_{230}\right)$ were quantified spectrophotometrically in a NanoDrop ND-1000 (NanoDrop Technologies, DE).

qPCR assay. To quantify the $F$. graminearum DNA concentration in the soybean roots a qPCR IDT PrimeTime gene expression master mix assay was designed to amplify the translation elongation (tefl $\alpha)$ gene of $F$. graminearum. The PCR amplifications were performed in total volumes of $15 \mu \mathrm{l}$ using a 96-well microwell plates, each reaction contained: $13 \mu \mathrm{l}$ of master mix, $1 \mu \mathrm{l}(10 \mu \mathrm{mol} /$ liter) of forward primer (5'-CTGCCCTCTTCCCACA-3'), $1 \mu \mathrm{l}$ (10 $\mu \mathrm{mol} / \mathrm{liter})$ of reverse primer $\left(5^{\prime}\right.$-AGAACCCAGGCG TACTTG- $\left.3^{\prime}\right)$, and $0.375 \mu \mathrm{l}(10 \mu \mathrm{mol} / \mathrm{liter})$ of probe $\left(5^{\prime}\right.$-FAM CCACCTGTC/ZEN/ATTAGGAAGC-3'). Amplifications were performed using a Bio-Rad CFX384 C1000 Touch thermal cycler (Bio-Rad Laboratories, CA), in which thermal cycling conditions consisted of one cycle of $95^{\circ} \mathrm{C}$ for $3 \mathrm{~min}, 40$ cycles of $95^{\circ} \mathrm{C}$ for $15 \mathrm{~s}$ followed by one cycle of $60^{\circ} \mathrm{C}$ for $1 \mathrm{~min}$.

DNA standard curves were obtained from 10-fold serial dilutions of fungal DNA (FG5 isolate), using three replicates of six concentrations $\left(1: 1,1: 10,1: 10^{2}, 1: 10^{3}, 1: 10^{4}\right.$, and 1:105) in sterile ultrapure water. The cycle threshold $(\mathrm{Ct})$ values obtained from each dilution series were used to calculate the value of the target DNA. The correlations between the $\mathrm{Ct}$ values and the DNA quantities was high for $F$. graminearum $\left(R^{2}=0.9951\right)$. Both ultrapure water and roots from the noninfested pots were used as negative controls for the $\mathrm{qPCR}$ reactions.

Data analysis. Visual root rot severity data (\%) was arcsine transformed. Root length, surface area, root volume, root tips, forks, foliar area, and shoot and root dry weight were square root transformed to meet the assumptions of analysis of variance. In addition, normal distribution of the residuals were tested for all the transformed data under the PROC UNIVARIATE procedure of SAS version 9.3 (SAS Institute Inc., Cary, CNC). Separate analysis of the two experimental replications showed similar trends, so data were combined for subsequent analyses. Analysis of variance was performed on the transformed data using PROC GLIMMIX in which the main-plot effect, soil moisture, was tested against the whole-plot variation error, and subplot effects were tested against the residual variability. Mean separation analyses on the transformed data were performed using a Fisher's protected least significant difference (LSD) test at $P=0.05$. In addition, correlations using the PROC CORR statement were performed to compare the average of root rot severity (\%) and fungal DNA quantity in the root tissue of plants growing on infested soil at $\mathrm{pH} 6$.

\section{RESULTS}

Root rot severity. The analysis of variance indicated a significant effect for the main factors soil moisture content $\left(\theta_{\mathrm{v}}\right)$, soil $\mathrm{pH}$, and soil texture, as well as the interaction between $\theta_{\mathrm{v}}$ and soil texture $(P<0.0001)$ for the visual evaluation of root rot (Table 3). These significant interactions indicate that the level of disease varied across the soil textures and the effect of soil moisture content varied among soil textures, primarily because soil moisture content did not affect root rot in sand.

Soil $\mathrm{pH}$ significantly influenced disease severity. Soil at $\mathrm{pH} 6$ showed more disease in all treatment combinations compared with pH 8 (Fig. 1). Overall, across soil textures, the highest level of root rot was observed at $\mathrm{pH} 6$ and PWP $(55.3 \%)$; and the lowest level of disease was observed at $\mathrm{pH} 8$ and PS (15.4\%) (Fig. 1A).

The effects of soil moisture and soil texture on root rot severity displayed similar trends for $\mathrm{pH} 6$ and 8 . Root rot severity increased in the finer textured soils at PWP. Conversely, disease severity decreased in the finer textured soils at PS; therefore, PWP and PS demonstrated inverse trends on root rot severity. Disease severity at FC remained between the highest and lowest disease levels in each soil texture. In addition, there were no significant differences in the levels of disease across the soil moisture levels in the sand treatment (Fig. 2).

The highest levels of disease occurred in loamy sand and sandy loam soils at PWP at both $\mathrm{pH}$ levels (Fig. 2). At soil pH 6, the highest levels of disease were 52.6 and $67 \%$, in loamy sand and sandy loam soils, respectively, whereas at $\mathrm{pH} 8$, they were 51.7 and $49.8 \%$. In contrast, the lowest levels of root rot were found in sandy loam and loam soils (10.2 and 9.7\%, respectively) at PS and soil $\mathrm{pH} 8$

TABLE 2. Values of volumetric water content of soils of varying soil textures ${ }^{\mathrm{a}}$

\begin{tabular}{lccc}
\hline & \multicolumn{3}{c}{ Soil volumetric water content $\left(\theta_{\mathrm{v}}\right)$} \\
\cline { 2 - 4 } Soil textures & PS & FC & PWP \\
\hline Sand & 0.13 & 0.09 & 0.07 \\
Loamy sand & 0.16 & 0.10 & 0.08 \\
Sandy loam & 0.25 & 0.17 & 0.09 \\
Loam & 0.28 & 0.21 & 0.11 \\
\hline
\end{tabular}

a Soil moisture levels: $\mathrm{PS}=$ pot saturation, $\mathrm{FC}=$ field capacity, and $\mathrm{PWP}=$ permanent wilting point.

TABLE 1. Artificial soil textural classes generated by sand and silt loam mix ${ }^{\mathrm{a}}$

\begin{tabular}{|c|c|c|c|c|c|c|}
\hline \multicolumn{2}{|c|}{ Soil mix by volume } & \multicolumn{5}{|c|}{ Particle size distribution analysis } \\
\hline Sand $(\%)$ & Silt loam $(\%)$ & Textural class & Sand $(\%)$ & Silt $(\%)$ & Fine silt $(\%)$ & Clay $(\%)$ \\
\hline 90 & 10 & Sand & 95.90 & 1.49 & 1.94 & 0.67 \\
\hline 75 & 25 & Loamy sand & 87.14 & 4.62 & 3.96 & 4.28 \\
\hline 25 & 75 & Sandy loam & 61.94 & 13.67 & 11.84 & 12.55 \\
\hline 10 & 90 & Loam & 42.10 & 19.05 & 19.88 & 18.97 \\
\hline
\end{tabular}

a Particle size distribution analyses for the artificial soil textural classes obtained using the pipette method. 
(Fig. 2B), followed by sandy loam and loam soils (21.5 and $19.9 \%$, respectively) at PS and soil pH 6 (Fig. 2A).

Effects on seedling growth variables. Comparisons between $F$. graminearum-infested and noninfested treatments revealed detrimental effects on shoot and root morphological characteristics, especially in loamy sand and sandy loam soils (Table 4). Plants growing in F. graminearum-infested soils had significantly shorter roots compared with the noninfested control in loamy sand and sandy loam soil textures at all soil moisture levels. In contrast, root length was not affected by $F$. graminearum when plants were grown in sand (Fig. 3A).

There were significant detrimental effects on foliar area for F. graminearum-infested sandy loam soil at all soil moisture content levels, and loam soil at PS. Conversely, foliar area was significantly higher in the infested treatments compared with noninfested treatments in sandy soils at FC and PWP (Fig. 3B).

TABLE 3. Analysis of variance indicating the effects of soil moisture content, soil $\mathrm{pH}$, and soil texture on visual root rot severity (\%), following soil infestation with Fusarium graminearum ${ }^{\mathrm{a}}$

\begin{tabular}{lcrr}
\hline Source & df & $F$ value & $P>F$ \\
\hline Soil moisture content $\left(\theta_{\mathrm{v}}\right)$ & 2 & 73.09 & $<0.0001$ \\
Soil $\mathrm{pH}(\mathrm{pH})$ & 1 & 50.42 & $<0.0001$ \\
$\theta_{\mathrm{v}} \times \mathrm{pH}$ & 2 & 0.57 & 0.5675 \\
Soil texture $(\mathrm{ST})$ & 3 & 14.51 & $<0.0001$ \\
$\theta_{\mathrm{v}} \times \mathrm{ST}$ & 6 & 16.66 & $<0.0001$ \\
$\mathrm{pH} \times \mathrm{ST}$ & 3 & 1.40 & 0.2406 \\
$\theta_{\mathrm{v}} \times \mathrm{pH} \times \mathrm{ST}$ & 6 & 0.77 & 0.5956 \\
\hline
\end{tabular}

a Analysis of variance was performed on the $F$. graminearum-infested plants only. Visual root rot disease data $(\%)$ were arcsine transformed. The experiment consisted of eight reps in a split-plot design, with soil moisture content as the main-plot factor, and soil $\mathrm{pH}$ and soil texture as the subplot factors.
Root and shoot dry weight were negatively affected by $F$. graminearum in sandy loam soil at PS and FC. However, there were no detrimental effects on root dry weight for the plants growing in infested sand (Fig. 3C and D).

Root volume was significantly affected by $F$. graminearum. There were significant differences in root volume between infested and noninfested plants for all soil textures and soil moisture treatments except for sand (Fig. 3E). Number of root tips was significantly affected by $F$. graminearum root infection in sandy loam and loam soils but no adverse effects were observed in sand or loamy sand soils (Fig. 3F).

The greatest reductions in the root and shoot morphological characteristics occurred in $F$. graminearum-infested sandy loam soils (Fig. 4). The greatest reductions in root length were observed in sandy loam soils in all levels of soil moisture (21 to 26\%) followed by loam soil at FC (18.6\%) (Fig. 4A). Foliar area was significantly reduced in sandy loam soil at PWP (53.2\%) followed by PS $(23.7 \%)$. Loamy sand and sand had no reductions in foliar area associated with $F$. graminearum (Fig. 4B).

Greatest reductions in root dry weight were observed in sandy loam and loam soils at PS and FC, ranging from 2 to $27 \%$. In addition, there was no reduction in root dry weight at PWP across all soil textures (Fig. 4C). Similarly, there were significant reductions in shoot dry weight in sandy loam and loam soils ranging from 3 to $19 \%$. Seedlings growing in loamy sand and sand did not display reductions in shoot dry weight (Fig. 4D).

Greatest reductions in root volume were observed in plants growing in sandy loam soils in all soil moisture treatments, followed by loamy and sandy loam soils at FC and PS (Fig. 4E). Reductions in number of root tips were significantly higher (6.5 to $16.2 \%)$ in plants growing in sandy loam soils (Fig. 4F). No reductions in shoot and root morphological characteristics were observed in the sand treatment.

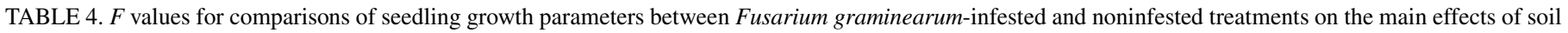
texture and soil moisture $(\mathrm{PS}=$ pot saturation, $\mathrm{FC}=$ field capacity, $\mathrm{PWP}=$ permanent wilting point $)$ at different soil $\mathrm{pH}^{\mathrm{a}}$

\begin{tabular}{|c|c|c|c|c|c|c|c|c|c|}
\hline \multirow[b]{2}{*}{ Soil texture } & \multicolumn{9}{|c|}{$\mathrm{pH} 6$} \\
\hline & $\theta_{\mathrm{v}}$ & RL & FA & RDW & SDW & RV & RT & SA & $\mathrm{F}$ \\
\hline \multirow[t]{3}{*}{ Sand } & PS & 1.71 & 0.04 & 0.83 & 0.85 & 0.05 & 1.18 & 0.62 & 2.65 \\
\hline & $\mathrm{FC}$ & 2.24 & 2.65 & 2.48 & 3.06 & 0.37 & 0.95 & 1.08 & 3.05 \\
\hline & PWP & 2.06 & 0.50 & 0.85 & 0.32 & 1.94 & 1.77 & 2.05 & $5.06 *$ \\
\hline \multirow[t]{3}{*}{ Loamy sand } & PS & 3.27 & 0.01 & 3.30 & 0.41 & 2.86 & 0.14 & 3.56 & 0.10 \\
\hline & $\mathrm{FC}$ & 1.76 & 0.49 & 0.83 & 0.17 & 3.88 & 0.07 & 2.95 & 0.60 \\
\hline & PWP & $7.06^{*}$ & 0.66 & 2.61 & 0.06 & $15.75^{*}$ & 0.01 & $11.37 *$ & 0.31 \\
\hline \multirow[t]{3}{*}{ Sandy loam } & PS & $33.75 *$ & $22.67 *$ & $26.38 *$ & $23.25^{*}$ & $50.74 *$ & $9.40^{*}$ & $45.05 *$ & $18.17 *$ \\
\hline & $\mathrm{FC}$ & $14.98 *$ & 1.66 & 2.06 & $5.90 *$ & $12.76^{*}$ & $7.38 *$ & $14.37 *$ & $13.33^{*}$ \\
\hline & PWP & $9.27 *$ & $15.20 *$ & 3.53 & 3.92 & $22.67^{*}$ & 0.66 & $16.01 *$ & 2.85 \\
\hline \multirow[t]{4}{*}{ Loam } & PS & $10.45^{*}$ & $8.95^{*}$ & $13.51 *$ & $5.93 *$ & $15.97^{*}$ & $3.25^{*}$ & $13.98 *$ & 1.63 \\
\hline & $\mathrm{FC}$ & $5.38 *$ & 0.36 & $5.08^{*}$ & 0.65 & $12.98^{*}$ & 1.24 & $9.13^{*}$ & 2.19 \\
\hline & PWP & 2.32 & $6.52 *$ & 0.71 & 1.78 & 4.77 & 0.38 & 3.84 & 0.01 \\
\hline & \multicolumn{9}{|c|}{$\mathrm{pH} 8$} \\
\hline Soil texture & $\theta_{\mathrm{v}}$ & RL & FA & RDW & SDW & RV & RT & SA & $\mathrm{F}$ \\
\hline \multirow[t]{3}{*}{ Sand } & PS & 1.25 & 1.96 & 0.17 & $6.13^{*}$ & 0.04 & 1.29 & 0.41 & 1.03 \\
\hline & $\mathrm{FC}$ & 0.51 & 3.81 & 0.78 & $11.74^{*}$ & 0.38 & 0.10 & 0.49 & 0.28 \\
\hline & PWP & 0.04 & $8.87 *$ & 1.81 & 2.94 & 0.05 & 0.67 & 0.25 & 0.70 \\
\hline \multirow[t]{3}{*}{ Loamy sand } & PS & 1.33 & 0.36 & 0.36 & 0.02 & $5.48 *$ & 1.07 & 3.26 & 0.08 \\
\hline & $\mathrm{FC}$ & 9.90 & 0.74 & 0.52 & 0.13 & $5.06^{*}$ & 1.13 & $7.65^{*}$ & $7.29 *$ \\
\hline & PWP & 0.37 & 0.18 & 0.04 & 0.10 & 1.47 & 0.84 & 0.90 & 0.13 \\
\hline \multirow[t]{3}{*}{ Sandy loam } & PS & 2.74 & 3.19 & $4.68 *$ & 2.34 & 3.89 & 1.65 & 3.44 & 1.39 \\
\hline & $\mathrm{FC}$ & $8.86^{*}$ & $7.86^{*}$ & $10.93 *$ & $13.06^{*}$ & $17.07^{*}$ & 2.46 & $13.91 *$ & $11.32 *$ \\
\hline & PWP & $7.01 *$ & $4.48 *$ & 0.01 & 2.04 & $16.66^{*}$ & 2.84 & $12.30 *$ & 2.84 \\
\hline \multirow[t]{3}{*}{ Loam } & PS & 0.27 & 0.01 & 0.71 & 0.02 & 1.45 & 2.14 & 0.17 & $5.15^{*}$ \\
\hline & $\mathrm{FC}$ & $8.78 *$ & 3.16 & $4.93 *$ & 0.12 & $8.60 *$ & $5.29 *$ & $8.81 *$ & $5.46^{*}$ \\
\hline & PWP & 0.54 & 0.29 & 0.39 & 1.56 & 2.49 & $5.71 *$ & 0.15 & 2.40 \\
\hline
\end{tabular}

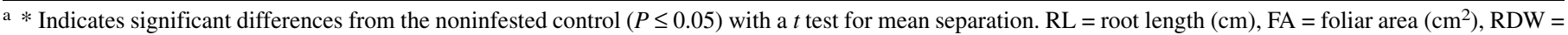
root dry weight $(\mathrm{g}), \mathrm{SDW}=$ shoot dry weight $(\mathrm{g}), \mathrm{RV}=$ root volume $\left(\mathrm{cm}^{3}\right), \mathrm{RT}=$ root tips, $\mathrm{SA}=$ surface area, and $\mathrm{F}=\mathrm{forks}$. Data represent values for two experiments with 16 observations per treatment combination. Analyses were performed on square root transformed data.
} 
Comparison between qPCR and visual evaluation of root rot severity. The $\mathrm{qPCR}$ protocol was highly sensitive and $F$. graminearum DNA was detected in all the roots grown in artificially infested soils. Plants growing at PWP had the greatest amount of fungal DNA in all the soil textures. However, the highest levels of fungal DNA were observed in sandy loam and loam soil textures at PWP; conversely, a significantly lower amount of fungal DNA was measured in all soil textures at PS and FC (Fig. 5A).

The effects of soil moisture and soil texture on the amount of F. graminearum DNA displayed similar trends to the visual evaluation of root rot severity (Figs. 2A and 5A), although fungal DNA was relatively low in sand compared with the root rot ratings. The amount of $F$. graminearum DNA was lowest in sand and generally increased with finer soil textures. Estimations of the amount of $F$. graminearum DNA in the root tissues by the qPCR assay and the visual evaluations of root rot severity in plants growing on $F$. graminearum-infested soil were positively and significantly correlated ( $r=0.6946, P=0.0121)$ (Fig. 5B).

The quantity of fungal DNA in root tissues was negatively correlated with seedling growth parameters including, foliar area $(r=-0.6536, P=0.0211)$, root volume $(r=-0.7536, P=0.0046)$, shoot dry weight $(r=-0.7117, P=0.0091)$, root length $(r=-0.8092$, $P=0.0014)$, and root dry weight $(r=-0.8791, P=0.0001)$ (Fig. 5C and D).

\section{DISCUSSION}

In this study, we provided the first analysis concerning the interactions among several abiotic soil factors (soil moisture, soil $\mathrm{pH}$, and soil texture) in the development of root rot of soybean seedlings caused by $F$. graminearum. The results suggest that edaphic characteristics have a considerable influence on disease
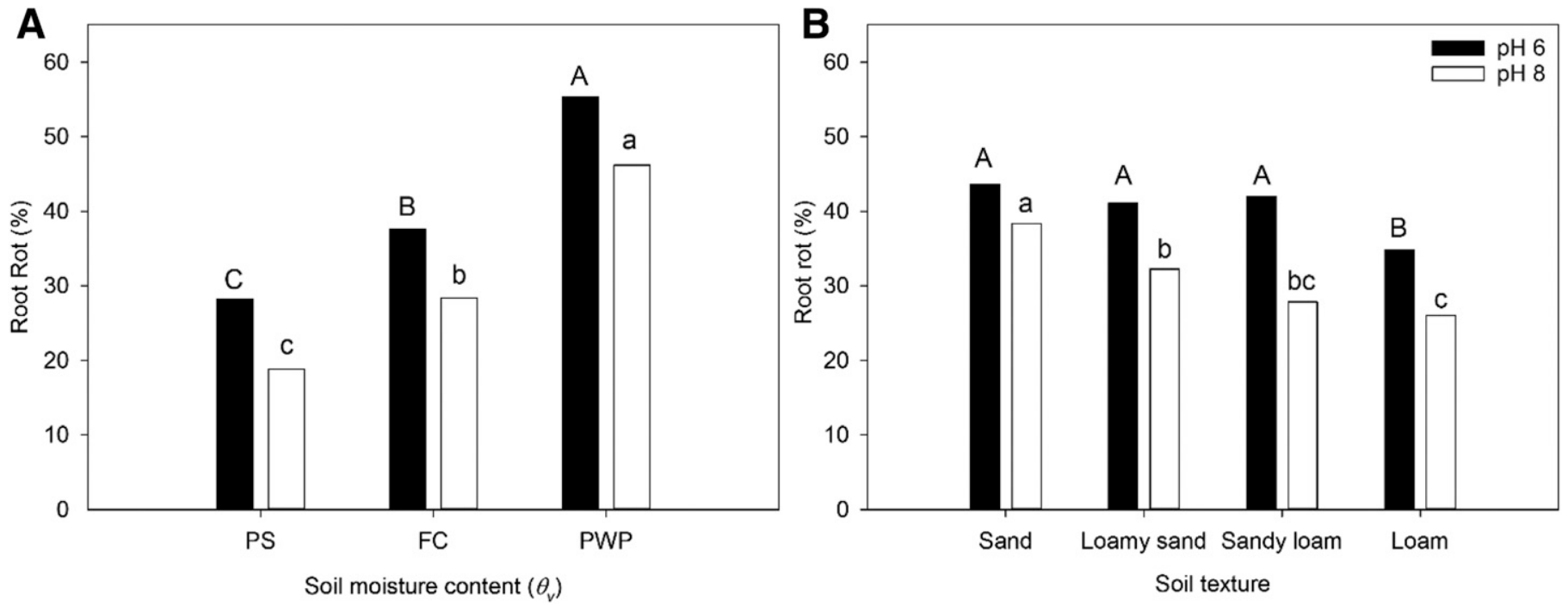

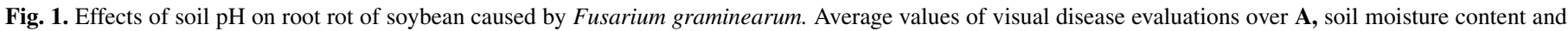

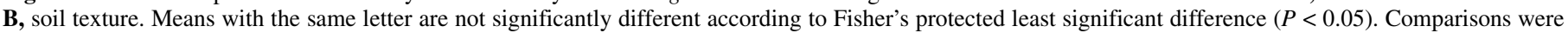

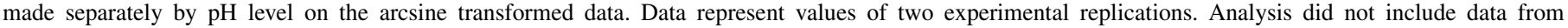
noninfested plants. $\mathrm{PS}=$ pot saturation, $\mathrm{FC}=$ field capacity, and $\mathrm{PWP}=$ permanent wilting point.
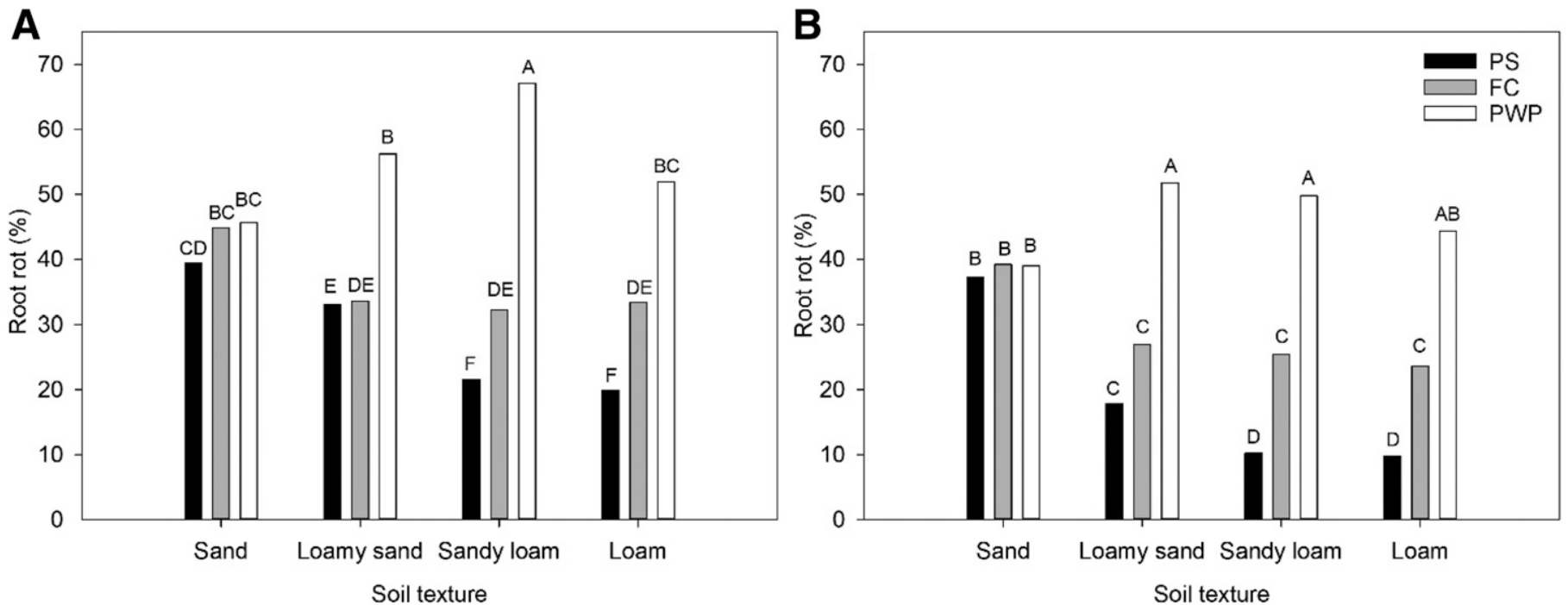

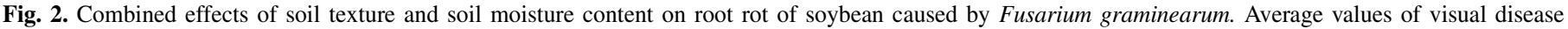

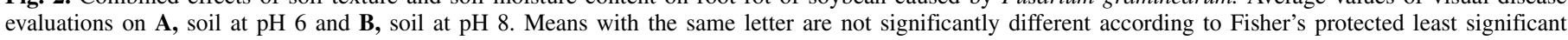

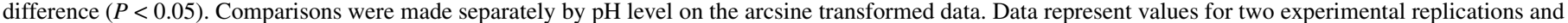
do not include data from noninfested plants. PS = pot saturation, FC = field capacity, and PWP = permanent wilting point. 
severity and seedling development. A somewhat acidic soil $\mathrm{pH}(\mathrm{pH}$ 6) was more conducive for root rot than an alkaline $\mathrm{pH}$ ( $\mathrm{pH} 8$ ). Root rot severity was significantly affected by the soil moisture treatments, of which PWP displayed the highest levels of root rot and PS the lowest, suggesting that moisture-stress conditions favor development of root rot caused by $F$. graminearum.

Our findings that disease was more severe under acidic soil conditions ( $\mathrm{pH} \mathrm{6)}$ agree with several similar studies. For example, sorghum root infection by $F$. graminearum was significantly higher at soil pH 5.1 than at pH 6.1 on seedlings 36 days after planting under field conditions (Davis et al. 1994). Strawberries infected by F. oxysporum f. sp. fragariae displayed more severe root rot and reduced plant size at pH 5.2 than at 7.5 (Fang et al. 2012). Increasing soil $\mathrm{pH}$ has been suggested as an alternative for disease management in other Fusarium wilt diseases such as banana, spinach, tomato, cotton, and melons (Dominguez et al. 1996; Gatch
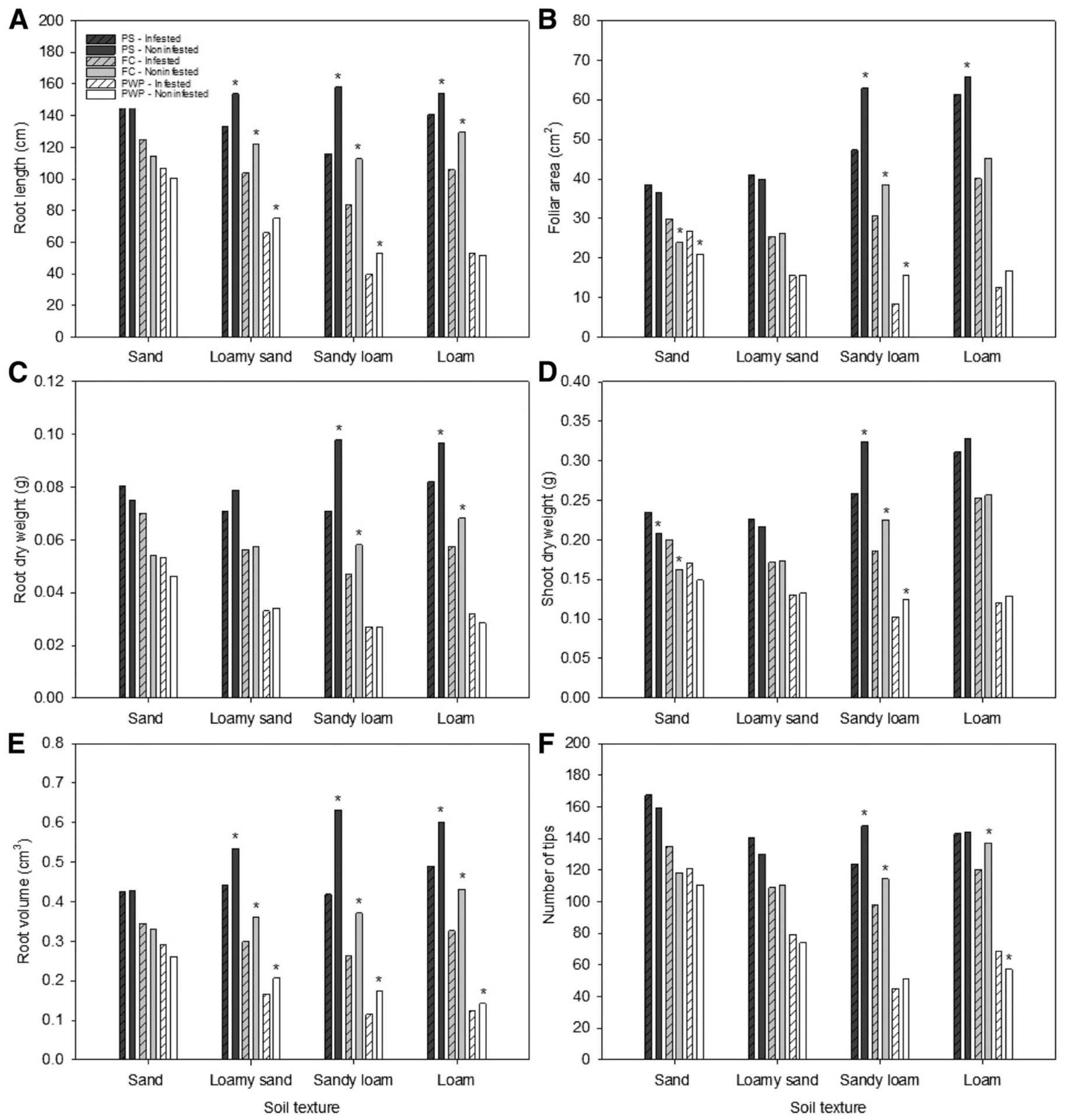

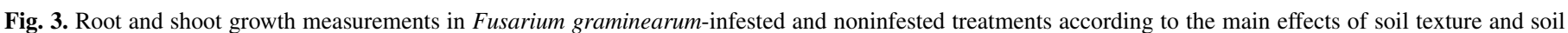

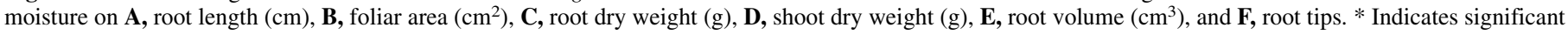

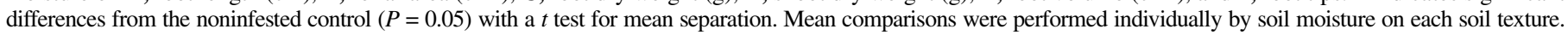

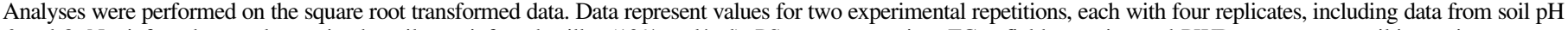
6 and 8. Noninfested control contained sterile noninfested millet $(10 \%$, vol/vol $)$. PS = pot saturation, FC = field capacity, and PWP $=$ permanent wilting point. 
and du Toit 2017; Groenewald et al. 2006; Jones et al. 1989; Woltz and Jones 1973). It seems plausible that increasing soil pH with $\mathrm{CaCO}_{3}$ might have reduced growth of $F$. graminearum, decreasing the chances to effectively infect soybean roots.

Previous reports suggest that increasing soil $\mathrm{pH}$ by liming reduces soil fungal populations and at the same time improves bacterial growth (Alabouvette 1999; Muhlbachova and Tlustos 2006; Scher and Baker 1980). According to our observations, increasing the soil $\mathrm{pH}$ with $\mathrm{CaCO}_{3}$ significantly reduced root rot severity caused by $F$. graminearum during a 4-week period.

High soil pH can lead to IDC in soybean, which is associated with root rot symptoms often attributed to Fusarium spp. However, our
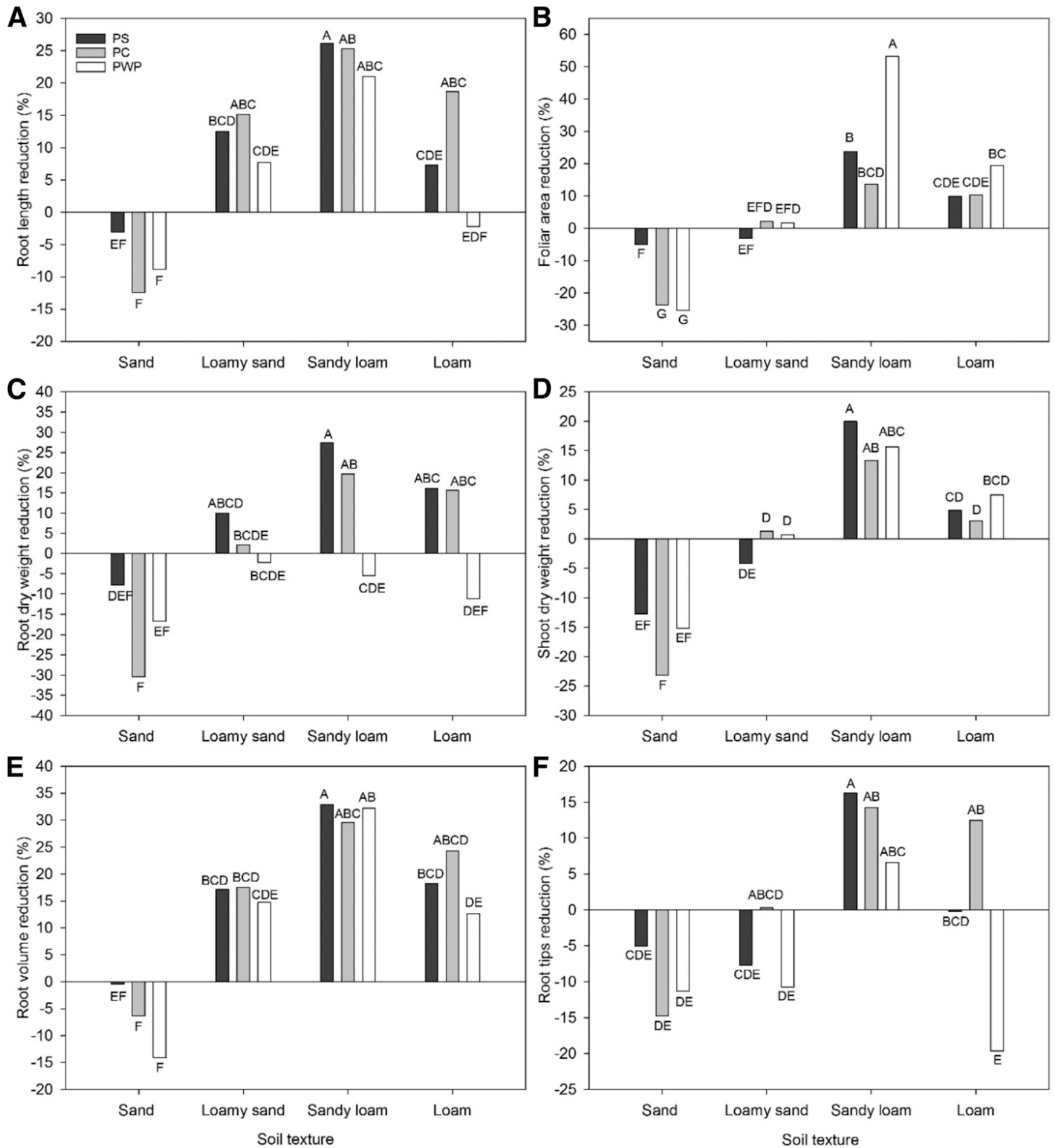

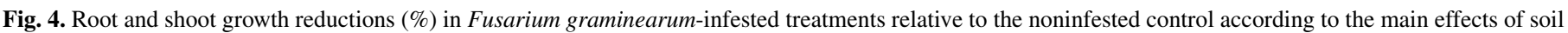

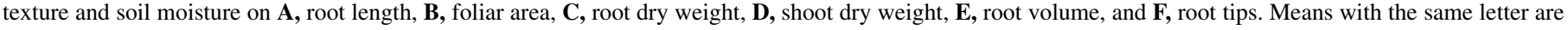

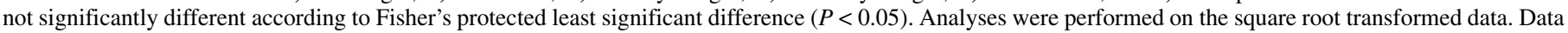

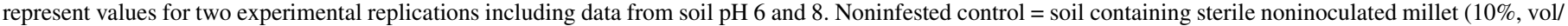
vol). $\mathrm{PS}=$ pot saturation, $\mathrm{FC}=$ field capacity, and $\mathrm{PWP}=$ permanent wilting point. 
results do not support a role for $F$. graminearum in enhanced root rot symptoms under high $\mathrm{pH}$ conditions. Root rots associated with IDC are likely caused by other fungal species (Hansen et al. 2004).

In our studies, the effect of soil moisture differed among the soil types. In sand, root rot severity was relatively high for all soil moisture levels; the PWP treatment had the highest value but was not significantly different from FC or PS. In loamy sand, PWP had the highest severity and there was no difference between FC and PS at $\mathrm{pH}$ 6. In the finer-textured soils (sandy loam and loam at $\mathrm{pH} 6$; loamy sand, sandy loam, and loam at $\mathrm{pH} \mathrm{8),} \mathrm{there} \mathrm{was} \mathrm{a} \mathrm{distinct}$ pattern of increasing root rot with decreasing soil moisture. Together, these results reinforce the conclusion that root rot was enhanced under moisture-stress conditions. In sand, plant moisture stress may have been similar in all the moisture content treatments, due to rapid drainage of water added to the cups. The interaction of soil texture with soil $\mathrm{pH}$ was not significant, but a trend toward lower root rot severity with higher clay content was more evident at $\mathrm{pH} 8$ than at $\mathrm{pH}$ 6. This observation is consistent with previous reports by Hoper et al. (1995) and Amir and Alabouvette (1993) on Fusarium wilts, which demonstrated that addition of clay (montmorillonite or illite) provides the most disease suppression at high soil $\mathrm{pH}$.

Soil texture affects plant disease due to the correlation with water holding capacity, nutrient availability, porosity and root growth
(Ghorbani et al. 2008). In our studies, we observed that the combined effect of soil texture and soil moisture displayed a marked influence on disease severity. For example, there were no significant differences in root rot across soil moisture contents in sand and this may be partially attributed to the fact that the volumetric water content differed very little among soil moisture treatments ranging from 0.07 to 0.13 . In addition, the highest levels of root rot were observed in soil treatments with volumetric water contents equal to or below 0.13 . Conversely, the effects of soil moisture treatment on root rot severity became more accentuated with incrementally higher clay content across soil textures, suggesting that the water holding capacity effect of clay played an important role in avoiding moisture stress conditions that favored root rot by F. graminearum.

Root rot was significantly higher at PWP soil moisture treatments in all soil textures except sand. Similar results regarding drought stress predisposing soybean to root infection by diverse Fusarium spp. have been described by Han et al. (2017). Similarly, in cereals, $F$. graminearum tends to be the most predominant Fusarium species in the warmer regions of the United States, and warm and dry weather is considered to be the optimal condition for root rot development (Beddis and Burgess 1992; Doohan et al. 2003; Vigier et al. 1997). It is likely that there is an association between dry climatic conditions optimal for $F$. graminearum to produce disease and our observation on root rot of soybean.
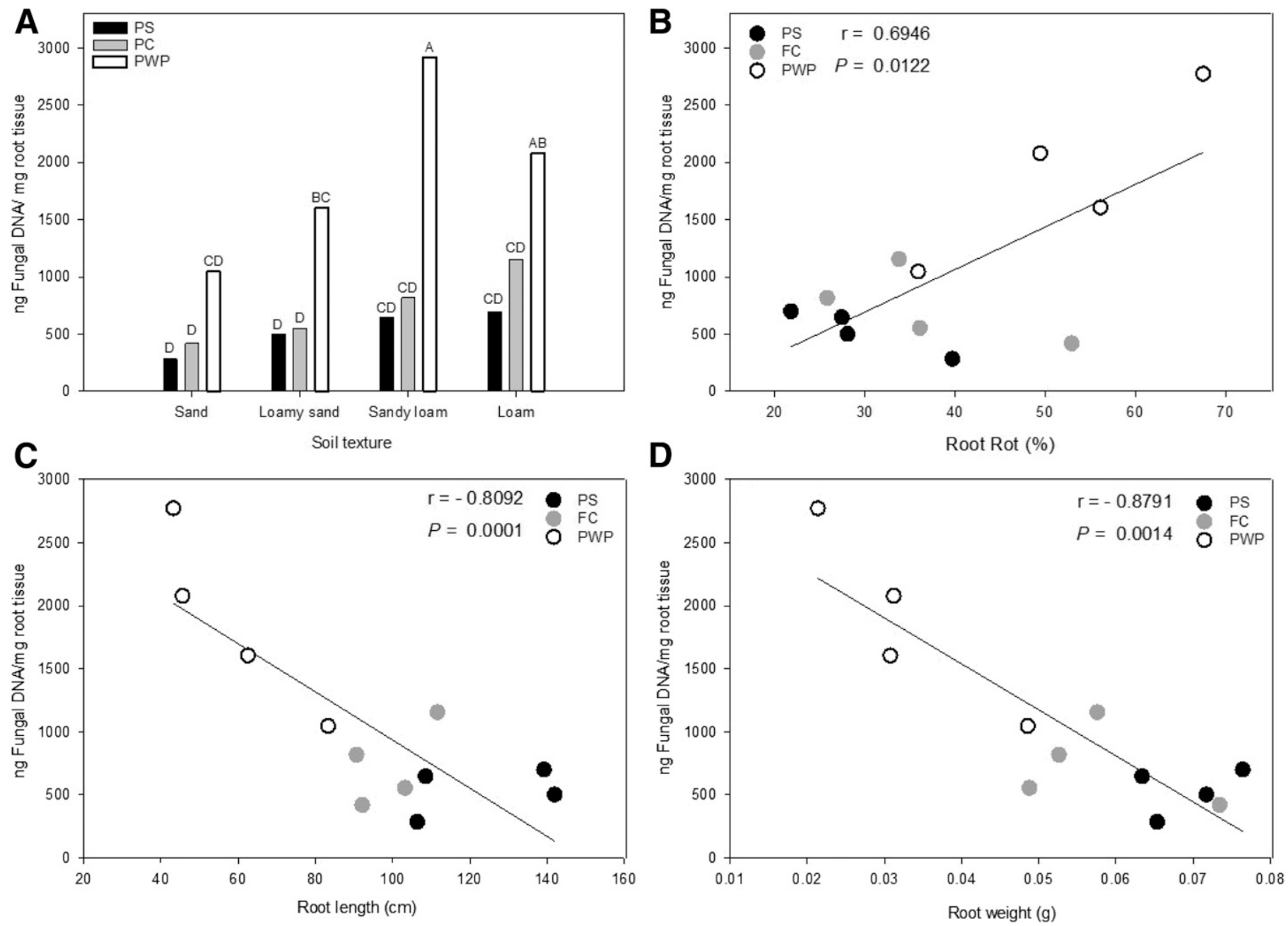

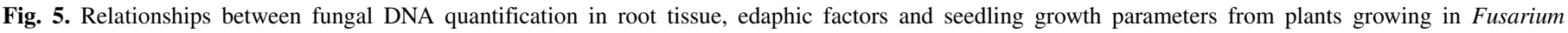

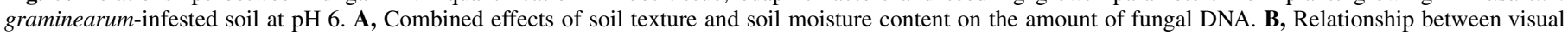

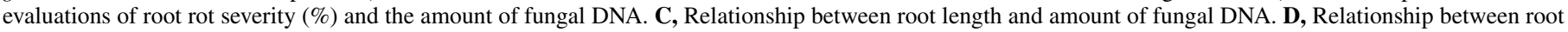

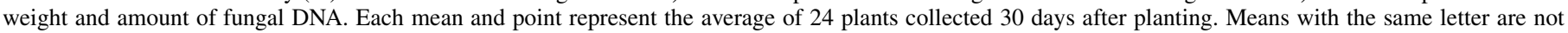

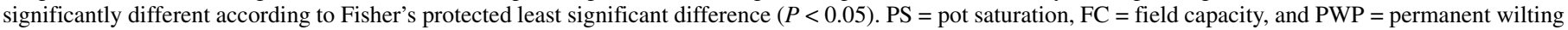
point. 
Soybean seedlings growing in soils at PWP displayed reduced root and shoot growth. The effects of low water stress in soybean include inhibition of cell division, reduction in foliar area, suppression of shoot, root growth, and root volume, and decrease in photosynthetic rate (Hossain et al. 2014; Krizek et al. 1985). Although studying the adverse effects of water stress on soybean seedling growth parameters was not our main objective, it is important to note that the highest levels of root rot were observed on water-stressed seedlings with reduced growth in root and shoot. For these reasons, it was more informative to draw conclusions on the effects of our treatments on plant growth variables by making comparisons between the infested and noninfested seedlings in each treatment combination. In this way we could evaluate the effects of the treatments on the disease, rather than their direct effects on seedling growth.

Soybean seedlings growing in F. graminearum-infested soils displayed significant reduction in plant growth parameters. These findings are in general agreement with Zhang et al. (2010) and Xue et al. (2007), in which seed or seedling $F$. graminearum inoculation reduced root dry weight and plant height up to 24 and $28 \%$, respectively. Reductions in root length, root volume, number of tips and forks by $F$. graminearum soil infestation has also been reported (Díaz Arias et al. 2013a). Differences in all plant growth parameters between infested and noninfested plants in sand were negligible. This effect is may be due in part to the low impedance for root elongation offered by the high sand content allowing the roots to scavenge, reducing detrimental effects of $F$. graminearum, also evident in the shoot weight and foliar area (Ballgar et al. 1980).

Highly significant differences were observed between the infested and noninfested treatments for all the root morphological variables in the PS and FC sandy loam soils, even though these treatment combinations had the lowest root rot severity. A possible explanation for the correlation between low root rot severity and high percentage of growth reduction is that the visual evaluation of disease does not take into account the loss of fine roots (or their failure to develop) when root infection takes place. It also does not account for internal root colonization and the possible damage in the vascular system that might affect root growth and development.

Root morphological characteristics analyzed on WinRhizo are useful indicators of root health. Estimates of root length, and root volume, root forks and root tips helped to interpret the detrimental effects of $F$. graminearum and its interactions with soil moisture, soil texture, and soil $\mathrm{pH}$. Root volume, however, seems to be the most sensitive variable in estimating detrimental effects of root rot. For example, there were significant differences in root volume comparing infested and noninfested treatments in all soil textures and soil moisture treatment combinations except for sand.

The amount of $F$. graminearum DNA was highly affected by the edaphic factors and demonstrated similar trends as the visual observations of root rot severity. The positive Pearson's correlation coefficients obtained from the comparison between the fungal DNA quantities and the visual observations of root rot severity evidence the qPCR assay's ability to quantify the target DNA and to indicate the extent of $F$. graminearum root colonization 30 days after planting. These results are consistent with those of Zhu et al. (2016), who reported significantly positive correlations between disease severity ratings and DNA quantities of $F$. commune in stem tissue of Chinese water chestnut (Eleocharis ducis).

Correlations between seedling growth parameters and fungal DNA quantities were significantly negative. These correlations correspond to short damaged roots with a high degree of fungal colonization and long, healthier roots harboring low quantities of fungal DNA. The best correlations between DNA quantity and root rot or root growth parameters occurred in the PWP treatments, which also displayed the highest of values for root rot and root growth. These results suggest that water-stressed seedlings are more predisposed to $F$. graminearum colonization, and the extended $F$. graminearum root colonization results in smaller underdeveloped roots. Similar observations have been described in which Fusarium spp. were more frequently isolated and able to colonize to a greater degree roots of well-drained soils resulted in lower root growth (Ali and Ghaffar 1991; Beddis and Burgess 1992; Han et al. 2017).

Additional studies will be needed to determine if the correlation between DNA quantities and visual observations of disease remain significant in later soybean stages. There is evidence that suggests that Fusarium spp. endophytic root colonization is dynamic and weather-dependent in other pathosystems (Bateman and Murray 2001; Hogg et al. 2010). It will be necessary to understand the impact of water stress in the root and rhizosphere under water stress that make the plant more susceptible to $F$. graminearum infection. Nevertheless, the evidence from our studies suggests that the ability of $F$. graminearum to colonize root tissues depends on the combination of edaphic factors, and these findings might have direct implications for future studies of $F$. graminearum populations.

The results from this study have provided information on abiotic factors of importance for root rot of soybeans caused by $F$. graminearum. It was demonstrated that changes in edaphic factors and their interactions influence disease severity and fungal root colonization. The soil parameters studied the most in relation to soilborne pathogens are soil $\mathrm{pH}$, clay content, and nitrogen content (Janvier et al. 2007). There are not many reports on Fusarium root diseases that included several soil factors in the same study and a combined approach is needed due to the possible interactions among biotic and abiotic factors related to soilborne diseases.

Additional variables such as temperature fluctuation and interactions between and within fungal species are needed. For example, Tu (1994) studied the effects of soil moisture and temperature on the Fusarium root rot complex of pea, including $F$. solani $\mathrm{f}$. sp. pisi and $F$. oxysporum $\mathrm{f}$. sp. pisi and found that both lack of moisture and saturation increased disease severity. It is important to study these types of interactions in the future since the soybean root rot complex of soybeans is not only associated with F. graminearum but includes a diverse number of Fusarium species (Díaz Arias et al. 2013a; Leslie et al. 1990).

\section{ACKNOWLEDGMENTS}

We thank S. Cianzio for providing the soybean cultivar used in this study, J. Wolt for his guidance in soil $\mathrm{pH}$ preparation, and $\mathrm{K}$. Goode for her assistance with the statistical analysis.

\section{LITERATURE CITED}

Alabouvette, C. 1999. Fusarium wilt suppressive soils: An example of diseasesuppressive soils. Austral. Plant Pathol. 28:57-64.

Alabouvette, C., Rouxel, F., and Louvet, J. 1979. Characteristics of Fusarium wilt suppressive soils and prospects for their utilization in biological control. Pages 165-182 in: Soil-Borne Plant Pathogens. B. Schippers and W. Gams, eds. Academic Press, London.

Ali, F., and Ghaffar, A. 1991. Effect of water stress on rhizosphere mycroflora and root infection of soybean. Pak. J. Bot. 23:135-139.

Amir, H., and Alabouvette, C. 1993. Involvement of soil abiotic factors in the mechanisms of soil suppressiveness to Fusarium wilts. Soil Biol. Biochem. 25:157-164.

Ballgar, V. C., Whisler, F. D., and Nash, V. E. 1980. Soybean seedling root growth as influenced by soil texture, matric suction and bulk density. Commun. Soil Sci. Plant Anal. 11:903-915.

Barros, G. G., Zanon, M. S. A., Chiotta, M. L., Reynoso, M. M., Scandiani, M. M., and Chulze, S. N. 2014. Pathogenicity of phylogenetic species in the Fusarium graminearum complex on soybean seedlings in Argentina. Eur. J. Plant Pathol. 138:215-222.

Bateman, G. L., and Murray, G. 2001. Seasonal variations in populations of Fusarium species in wheat-field soil. Appl. Soil Ecol. 18:117-128.

Beddis, A. L., and Burgess, L. W. 1992. The influence of plant water-stress on the infection and colonization of wheat seedlings by Fusarium graminearum group-1. Phytopathology 82:78-83.

Bhatti, M. A., and Kraft, J. M. 1992. Influence of soil moisture on root rot and wilt of chickpea. Plant Dis. 76:1259-1262. 
Brady, N. C., and Weil, R. R. 2004. Soil water: Characteristics and behavior. Pages 134-161 in: Elements of the Nature and Properties of Soils. N. C. Brady and R. R. Weil, eds. Prentice Hall, New Jersey.

Broders, K. D., Lipps, P. E., Paul, P. A., and Dorrance, A. E. 2007. Evaluation of Fusarium graminearum associated with corn and soybean seed and seedling disease in Ohio. Plant Dis. 91:1155-1160.

Cook, R. J., and Papendick, R. I. 1972. Influence of water potential of soils and plants on root disease. Annu. Rev. Phytopathol. 10:349-374.

Davis, M. A., Jardine, D. J., and Todd, T. C. 1994. Selected pre-emergent herbicides and soil $\mathrm{pH}$ effect on seedling blight of grain sorghum. J. Prod. Agric. 7:269-276.

Díaz Arias, M. M., Leandro, L. F., and Munkvold, G. P. 2013a. Aggressiveness of Fusarium species and impact of root infection on growth and yield of soybeans. Phytopathology 103:822-832.

Díaz Arias, M. M., Munkvold, G. P., Ellis, M. L., and Leandro, L. F. S. 2013 b. Distribution and frequency of Fusarium species associated with soybean roots in Iowa. Plant Dis. 97:1557-1562.

Dominguez, J., Negrin, M. A., and Rodriguez, C. M. 1996. Soil chemical characteristics in relation to Fusarium wilts in banana crops of Gran Canaria Island (Spain). Commun. Soil Sci. Plant Anal. 27:2649-2662.

Doohan, F. M., Brennan, J., and Cooke, B. M. 2003. Influence of climatic factors on Fusarium species pathogenic to cereals. Eur. J. Plant Pathol. 109:755-768.

Doyle, J. J., and Doyle, J. L. 1987. A rapid DNA isolation procedure for small quantities of fresh leaf tissue. Phytochem. Bull. 19:11-15.

Ellis, M. L., and Munkvold, G. P. 2014. Trichothecene genotype of Fusarium graminearum isolates from soybean (Glycine max) seedling and root diseases in the United States. Plant Dis. 98:1012.

Fang, X. L., You, M. P., and Barbetti, M. J. 2012. Reduced severity and impact of Fusarium wilt on strawberry by manipulation of soil $\mathrm{pH}$, soil organic amendments and crop rotation. Eur. J. Plant Pathol. 134:619-629.

French, E. R. 1963. Effect of soil temperature and moisture on the development of Fusarium root rot of soybean. Phytopathology 53:875.

Gatch, E. W., and du Toit, L. J. 2017. Limestone-mediated suppression of Fusarium wilt in spinach seed crops. Plant Dis. 101:81-94.

Ghorbani, R., Wilcockson, S., Koocheki, A., and Leifert, C. 2008. Soil management for sustainable crop disease control: A review. Environ. Chem. Lett. 6:149-162.

Graham, J. H., Sprague, V. G., and Robinson, R. R. 1957. Damping-off of Ladino clover and Lespedeza as affected by soil moisture and temperature. Phytopathology 47:182-185.

Greenshields, D. L., Guosheng, L., and Yangdou, W. 2007. Roles of iron in plant defence and fungal virulence. Plant Signal. Behav. 2:300-302.

Groenewald, S., van den Berg, N., Marasas, W. F. O., and Viljoen, A. 2006. Biological, physiological and pathogenic variation in a genetically homogenous population of Fusarium oxysporum f. sp. cubense. Austral. Plant Pathol. 35:401-409.

Han, G., Kandel, Y. R., Leandro, L. F. S., Helmers, M. J., Schott, L. R., and Mueller, D. S. 2017. Influence of drainage on soybean seedling health. J. Soil Water Conserv. 72:266-271.

Hansen, N. C., Jolley, V. D., Naeve, S. L., and Goos, R. L. 2004. Iron deficiency of soybean in the North Central U.S. and associated soil properties. Soil Sci. Plant Nutr. 50:983-987.

Hogg, A. C., Johnston, R. H., Johnston, J. A., Klouser, L., Kephart, K. D., and Dyer, A. T. 2010. Monitoring Fusarium crown rot populations in spring wheat residues using quantitative real-time polymerase chain reaction. Phytopathology 100:49-57.

Hoper, H., and Alabouvette, C. 1996. Importance of physical and chemical soil properties in the suppressiveness of soils to plant diseases. Eur. J. Soil Biol. 32:41-58.

Hoper, H., Steinberg, C., and Alabouvette, C. 1995. Involvement of clay type an $\mathrm{pH}$ in the mechanisms of soil suppressiveness to fusarium wilt of flax. Soil Biol. Biochem. 27:955-967.

Hossain, M. M., Liu, X., Qi, X., Lam, H.-M., and Zhang, J. 2014. Differences between soybean genotypes in physiological response to sequential soil drying and rewetting. Crop J. 2:366-380.

Islam, M. A., Milham, P. J., Dowling, P. M., Jacobs, B. C., and Garden, D. L. 2004. Improved procedures for adjusting soil $\mathrm{pH}$ for pot experiments. Commun. Soil Sci. Plant Anal. 35:25-37.

Janvier, C., Villeneuve, F., Alabouvette, C., Edel-Hermann, V., Mateille, T., and Steinberg, C. 2007. Soil health through soil disease suppression: Which strategy from descriptors to indicators? Soil Biol. Biochem. 39:1-23.

Jones, J. P., Engelhard, A. W., and Woltz, S. S. 1989. Management of Fusarium wilt of vegetables and ornamentals by macro- and microelement nutrition. Pages 18-32 in: Soilborne Plant Pathogens: Management of Diseases with Macro- and Microelements A. W. Engelhard, ed. American Phytopathological Society, St. Paul, MN.

Kirkpatrick, M. T., Rupe, J. C., and Rothrock, C. S. 2006. Soybean response to flooded soil conditions and the association with soilborne plant pathogenic genera. Plant Dis. 90:592-596.
Kosman, D. J. 2003. Molecular mechanisms of iron uptake in fungi. Mol. Microbiol. 47:1185-1197.

Krizek, D. T., Carmi, A., Mirecki, R. M., Snyder, F. W., and Bunce, J. A. 1985. Comparative effects of soil moisture stress and restricted root zone volume on morphogenetic and physiological responses of soybean. J. Exp. Bot. 36:25-38.

Landa, B. B., Navas-Cortes, J. A., Jimenez-Gasco, M. D., Katan, J., Refig, B., and Jimenez-Diaz, R. M. 2006. Temperature response of chickpea cultivars to races of Fusarium oxysporum $\mathrm{f}$. sp. ciceris, causal agent of fusarium wilt. Plant Dis. 90:365-374.

Leslie, J. F., Pearson, C. A. S., Nelson, P. E., and Toussoun, T. A. 1990. Fusarium spp. from corn, sorghum, and soybean fields in the central and eastern United States. Phytopathology 80:343-350.

Licht, M. A., Wright, D., and Lenssen, A. W. 2013. Planting soybean for high yield in Iowa. Iowa State University. Agriculture and Environment Extension Publications. Digital Repository. https://lib.dr.iastate.edu/extension ag_pubs/193

Lynch, J., and Vanbeem, J. J. 1993. Growth and architecture of seedling roots of common bean genotypes. Crop Sci. 33:1253-1257.

Martinelli, J. A., Bocchese, C. A. C., Xie, W. P., O’Donnell, K., and Kistler, H. C. 2004. Soybean pod blight and root rot caused by lineages of the Fusarium graminearum and the production of mycotoxins. Fitopatol. Bras. 29:492-498.

McLean, E. O., and Brown, J. R. 1984. Crop response to lime in the midwestern United States. Pages 267-303 in: Soil acidity and liming, 2nd Ed., F. Adams, ed. American Society of Agronomy, Inc., Madison, WI.

Muhlbachova, G., and Tlustos, P. 2006. Effects of liming on the microbial biomass and its activities in soils long-term contaminated by toxic elements. Plant Soil Environ. 52:345-352.

National Soil Survey Center. 1996. Soil survey laboratory methods manual. Method 3A. United States Department of Agriculture. Natural Resources Conservation Service, Lincoln, NE.

Navas-Cortes, J. A., Landa, B. B., Mendez-Rodriguez, M. A., and Jimenez-Diaz, R. M. 2007. Quantitative modeling of the effects of temperature and inoculum density of Fusarium oxysporum f. sp ciceris races 0 and 5 on development of Fusarium wilt in chickpea cultivars. Phytopathology 97:564-573.

Philpott, C. C. 2006. Iron uptake in fungi: A system for every source. Biochim. Biophys. Acta 1763:636-645.

Robert, M., and Chenu, C. 1992. Interactions between soil minerals and microorganisms. Pages 307-404 in: Soil Biochemistry, Vol. 7. G. Stotzky and J. M. Bollag, eds. Dekker Inc., New York.

Rogovska, N. P., Blackmer, A. M., and Mallarino, A. P. 2007. Relationships between soybean yield, soil $\mathrm{pH}$, and soil carbonate concentration. Soil Sci. Soc. Am. J. 71:1251-1256.

Rowell, D. L. 1994. The availability of water in soils. Pages 244-255 in: Soil Science: Methods and Applications. D. L. Rowell, ed. Longman Scientific \& Technical, Singapore.

Scher, F. M., and Baker, R. 1980. Mechanism of biological control in a Fusarium-suppressive soil. Phytopathology 70:412-417.

Sella, L., Gazzetti, K., Castiglioni, C., Schaefer, W., and Favaron, F. 2014. Fusarium graminearum possesses virulence factors common to Fusarium head blight of wheat and seedling rot of soybean but differing in their impact on disease severity. Phytopathology 104:1201-1207.

Stotzky, G., and Rem, L. T. 1966. Influence of clay minerals on microorganisms. Montmorillonite and Kaolinite on bacteria. Can. J. Microbiol. 12:547-563.

Strunnikova, O. K., Vishnevskaya, N. A., Ruchiy, A. S., Shakhnazarova, V. Y., Vorobyov, N. I., and Chebotar, V. K. 2015. The influence of soils with different textures on development, colonization capacity and interactions between Fusarium culmorum and Pseudomonas fluorescens in soil and on barley roots. Plant Soil 389:131-144.

Stutz, E., Kahr, G., and Defago, G. 1989. Clays involved in suppression of tobacco black root rot by a strain of Pseudomonas fluorescens. Soil Biol. Biochem. 21:361-366.

Toussoun, T. A. 1975. Fusarium-suppressive soils. Pages 151-154 in: Biology and Control of Soil-Borne Plant Pathogens. G. W. Bruehl, ed. American Phytopathological Society, St. Paul, MN.

Tu, J. C. 1994. Effects of soil compaction, temperature, and moisture on the development of the Fusarium root rot complex of pea in southwestern Ontario. Phytoprotection 75:125-131

Vigier, B., Reid, L. M., Seifert, K. A., Stewart, D. W., and Hamilton, R. I. 1997. Distribution and prediction of Fusarium species associated with maize ear rot in Ontario. Can. J. Plant Pathol. 19:60-65.

Watson, M. E., and Brown, J. R. 1997. pH and lime requirement. Pages 13-16 in: Recommended chemical soil test procedures for the north central region. J. R. Brown, ed. North Central Regional Research Publication.

Windels, C. E., Kommedahl, T., Stienstra, W. C., and Burnes, P. M. 1988. Occurrence of Fusarium species in symptom-free and overwintered cornstalks in Northwestern Minnesota. Plant Dis. 72:990-993.

Woltz, S. S., and Jones, J. P. 1973. Tomato Fusarium wilt control by adjustments in soil fertility. Proc. Fla. State Hortic. Soc. 86:157-159. 
Xue, A. G., Cober, E., Voldeng, H. D., Babcock, C., and Clear, R. M. 2007. Evaluation of the pathogenicity of Fusarium graminearum and Fusarium pseudograminearum on soybean seedlings under controlled conditions. Can. J. Plant Pathol. 29:35-40.

Yuen, G. Y., McCain, A. H., and Schroth, M. N. 1983. The relation of soil type to suppression of Fusarium wilt of carnation. Acta Hortic. 141:95-102.
Zhang, J. X., Xue, A. G., Zhang, H. J., Nagasawa, A. E., and Tambong, J. T. 2010. Response of soybean cultivars to root rot caused by Fusarium species. Can. J. Plant Sci. 90:767-776.

Zhu, Z. X., Zheng, L., Hsiang, T., Yang, G. L., Zhao, D. L., Lv, B., Chen, Y. F., and Huang, J. B. 2016. Detection and quantification of Fusarium commune in host tissue and infested soil using real-time PCR. Plant Pathol. 65:218-226. 